\title{
LOGGING WASTE IN THE DOUGLAS FIR-WEST- ERN CEDAR TYPE OF THE SOUTHERN COAST REGION OF BRITISH COLUMBIA.
}

\author{
By J. H. Jenkins and F. W. Guernsey, \\ Timber Products Division
}

$\mathbb{T}$

7 HE depletion of accessible standing timber has brought to the foreground the necessity for a closer utilization of timber as a means of husbanding forest resources. In order to determine how this closer utilization may be attained it is necessary to study the extent to which waste enters into wood utilization and to indicate how waste may be reduced to a minimum.

The Vancouver Laboratory of the Forest Products Laboratories of Canada, Forest Service, Department of the Interior, has already made studies dealing with the reduction of lumber waste due to faulty seasoning and with improvements in the manufacture of lumber so that better utilization may be obtained and the amount of waste reduced. However, the problem of wood waste begins in the woods and in order to cover the field of waste research and to tie in with the results already obtained from other studies, the logging waste studies herein reported upon were undertaken. This report is only a progress report and much intensive research remains to be carried out before a comprehensive survey of the problem of timber waste can be made available. In undertaking these studies, it was felt that the absence of reliable information on the character and extent of logging waste has seriously retarded sustained research directed to better utilization, and such research is imperative in order to determine the extent to which corrective measures are feasible.

Logging waste studies in British Columbia have been divided into two phases:-

Phase 1-A survey of the quantity and character of the material left in the wood after logging (commonly telmed "logging waste");

Phase 2-Reduction of logging waste by improving logging methods and by improved means of disposal.

The size of timber cut and the methods of logging and of lumber manufacture vary widely in the Coast and Interior regions of the Province, so that it will eventually be necessary to carry on studies at selected logging operations in both regions. On account of its greater importance as a log-producing region, special attention has so far been paid to the Southern Coast Region in which the Douglas fir-western cedar type is of chief importance. 
This Douglas fir-western cedar type is the main commercial type of the lower Coast and occurs at the lower elevations in southern, eastern, and central Vancouver island, and along the Mainland and adjacent islands to Knight inlet. Typical forests in this type are composed approximately of Douglas fir, 70 per cent; cedar 17 per cent; hemlock 6 per cent; the balance being composed of "true firs," white pine, and Sitka spruce. Powerful steam donkeys, operating high lead, sky line systems, etc., and logging railroads are the prominent features in the logging operations in this type. A considerable percentage of the timber cut in this type is logged by operators who are engaged solely in logging and are not connected with any sawmill operation. They cut their own timber and sell their logs in the open market.

The following report is a progress report on the work completed to date in connection with Phase 1 and deals only with the survey of logging waste in the Douglas fir-cedar type of the Southern Coast region of British Columbia.

It was neither possible nor necessary to make a waste survey at all logging operations in the Douglas fir-western cedar type. Representative operations were carefully selected throughout the range of this. type in order to provide a cross-section of the logging industry. At each operation selected, an intensive survey was made of the logging waste and the active co-operation of the management of each company was of marked assistance in enabling Laboratory officers to successfully complete this work.

The intensive waste survey was made at eight logging operations. Two of these operations were located in the lower Fraser valley, while the remaining six were located on Vancouver Island between Cowichan Lake and Campbell Lake. Sample plots were also located and cruised at a third operation in the Fraser valley, but fire prevented the completion of the study on this operation. A greater number of operations were selected on Vancouver Island on account of the concentration of the logging industry in this area at the present time.

This progress report is a summary of information contained in individual detailed confidential reports on each area studied, which were supplied to the participating operators only.

Before the field work was undertaken, visits were paid to a number of representative logging operations, and consultations were held with members of the logging industry in British Columbia and with the Office of Forest Products, United States Forest Service, Portland, Oregon, which has carried out a somewhat similar investigation in Washington and Oregon, as a result of which many valuable suggestions were received regarding procedure to be followed in the survey. A working plan was then prepared and, through the co-operation of the Secretary of the British Columbia Loggers' Association, copies were distributed throughout the industry for criticism. 
The same procedure was followed in making the waste survey at each of the eight logging operations studied. An inspection of the uncut timber was made, and, with the advice of the company's logging engineer and foreman, a suitable study area was selected. The area selected for study was generally a yarding side; i.e., the area from which the logs could be yarded or skidded by one donkey setting, and, as far as possible, was representative of the type being logged.

In each study area, two sample plots, each having an area of two acres, were carefully located so as to represent average timber and topographic conditions. On account of the debris after logging rendering difficult the selection and location of areas representative of average conditions, the sample plots were selected, marked, and cruised in the standing timber, generally only a few days in advance of the fallers.

In the examination of the sample plots prior to logging, the volume in feet board measure (f.b.m.) of all merchantable standing timber and sound windfalls was determined and a sketch contour map of the "setting" was prepared. This map showed the location of the spar tree and railroad in relation to the sample plots, the boundaries of the "setting" and other features affecting logging. In determining the volume of the standing timber, the top diameter limits, as shown in the volume tables of the B.C. Forest Branch for the species and localities studied, were used and no attempt was made, in this preliminary cruise, to estimate the volume of the material in the tops.

After the study area had been logged, the study crew returned to the area, re-ran the boundaries of the sample plots and made an intensive survey of the wood material left on the ground, recording the shape, size, and possible uses of this waste.

In measuring the material left on the ground after logging, all sound material, 4 feet or more in length and having a diameter at the small end of not less than 4 inches, was measured. To facilitate the measurement and identification of this waste, the sample plots were divided into rectangles onehalf chain wide by means of white tapes, and the wood material in each of these rectangles was measured by means of a scale stick. No attempt was made to distinguish between material that might be salvaged at a profit under present conditions and material that could obviously not be profitably utilized under present operating conditions and methods; that is, all sound material down to and including cordwood size was measured regardless of present value.

For convenience in tallying, the material left on the ground after logging was segregated into the following classes:-

Sawlogs-unbroken, sound, bucked at both ends.-These were merchantable sawlogs, with one or both ends broken instead of being sawn 
square. A deduction in the merchantable length of such logs to allow for trimming out the broken end was made in the tally.

Sawlogs containing rot.-This included only rotten logs which could be manufactured into lumber under present operating conditions.

Tops.-Top portion of the tree measured down to a diameter of 4 inches. Sound windfall or snag.- - Self explanatory.

Sawlog-shattered.-This included any sawlog which had been so badly damaged in logging as to render it useless for the manufacture of lumber.

Short sawlog, broken and bucked.-When a merchantable tree breaks in falling, it is customary to buck on both sides of the break. The short portion containing the break is left as waste. All such broken logs, less than 12 feet in length and exceeding 12 inches in diameter at the small end, were tallied under this classification.

Broken chunks.-This included all material (exclusive of tops) having diameters of 4 to 11 inches and 4 feet and over in length.

Small tree (knocked down).--This included any tree, with a diameter in excess of 6 inches, knocked down during the logging operation.

Large limbs.-This included all limbs or branches 4 inches and greater in diameter and 4 feet and over in length.

No attempt is being made at the present to utilize any of the material left on the ground aft:r the logging of the nine areas studied, and it may all therefore be classed as "logging waste." It is not intended to imply that all this mat:rial is avoidable waste nor that any great quantity of it could be utilized profitably under the present extremely low values for wood products. In tallying th:s material, however, attention was paid to its suitability for various uses and the following possible uses were distinguished:-

Sawlogs (min. length 12', min. top diam. 12").-Two arbitrary grades "A" and "B" were used for all species. These grades were based on quality and freedom from knots rather than on a basis of diameter.

Grade "A" included all logs of a quality (regardless of diameter) permitted in Grades \#1 and \#2 of the "B.C. Royalty Act."

Grade "B" included all logs of a quality permitted in Grade 3 of the "B.C. Royalty Act."

On account of their low value and for convenience in tabulating, all Grade "B" sawlogs are included with the pulpwood or cordwood, depending on their species, Grade " $A$ " sawlogs being the only ones tabulated under "sawlogs."

So that some idea could be obtained from the survey as to the size of sawlogs tallied as waste, they were arbitrarily segregated into three size classes, as follows:- 
"Small"-Logs containing less than 150 f.b.m.

"Medium"-Logs containing from 150 to 400 f.b.m.

"Large"- Logs containing over 400 f.b.m.

Poles and Piling.-Any timbers more valuable in this form than as sawlogs were classified according to the commercial specifications for Douglas fir and hemlock piling and cedar poles.

Shingle bolts. - Short or broken pieces of cedar not suitable for logs or poles and of a quality and size to make merchantable shingles.

Pulpwod.-Hemlock and spruce too small to be classified under the above headings.

Cordwood.-Douglas fir, cedar, and pine unsuitable for, or too small to be classified under any of the above headings.

No matetrial having a diameter less than 4 inches and shorter than 4 feet was measured. Rotten logs were not measured unless the defective portion was so located as to make practicable the salvage of the sound wood by cutting out the defect.

The results of all sudies made have been summarized from the individual reports showing the size, number of pieces, and volume of the waste on each of the study areas, and are presented in the following tables. In all these tables the data are shown on the basis of one acre, regardless of size and number of sample plots studied in each operation.

The results of the cruise of the timber on each study area, made prior to logging, are shown in Table 1. The volumes shown in this table include only merchantable timber measured to a commercial top diameter. The relation between feet board measure and cubic contents used in this table is based on data collected from mill studies made by this Laboratory on sawlogs cut in this region.

Table 2 shows the form or class of the wood material left on the ground after logging. The volumes used in this table are all in cubic feet, obtained from actual measurement of the waste.

TABLE 1.-VOLUME OF MERCHANTABLE TIMBER PER ACRE BEFORE LOGGING

\begin{tabular}{|c|c|c|c|c|c|c|c|c|c|}
\hline \multirow{2}{*}{ Species } & \multicolumn{8}{|c|}{ Logging Operation Studied } & \multirow{2}{*}{$\begin{array}{l}\text { Aver- } \\
\text { age }\end{array}$} \\
\hline & A & $B$ & C & $D$ & $\mathrm{E}$ & $\mathrm{G}$ & $\mathrm{H}$ & I & \\
\hline $\begin{array}{l}\text { Douglas fir..f.b.m. } \\
\text { Hemlock... f.b.m. } \\
\text { Cedar..... f.b.m. } \\
\text { Spruce. . . f.b.m. } \\
\text { White pine..f.b.m. }\end{array}$ & $\begin{array}{r}71,604 \\
32,289 \\
4,784 \\
\ldots \ldots\end{array}$ & $\begin{array}{r}74,659 \\
16,783 \\
5,432 \\
11,215\end{array}$ & $\begin{array}{r}83,671 \\
1,462 \\
14,068 \\
\ldots \\
\ldots\end{array}$ & $\begin{array}{r}95,419 \\
1,998 \\
525 \\
1,018\end{array}$ & $\begin{array}{r}81,127 \\
9,320 \\
3,741 \\
600 \\
\ldots\end{array}$ & $\begin{array}{r}69,091 \\
15,100 \\
860 \\
1,834\end{array}$ & $\begin{array}{r}30,390 \\
32,800 \\
\ldots\end{array}$ & $\begin{array}{r}42,019 \\
258 \\
3,487 \\
\ldots \\
\ldots\end{array}$ & $\begin{array}{r}68,498 \\
13,751 \\
4,112 \\
1,476 \\
357\end{array}$ \\
\hline $\begin{array}{r}\text { Total..... f.b.m. } \\
\text { cu. ft. }\end{array}$ & $\begin{array}{r}108,677 \\
17,816\end{array}$ & $\begin{array}{r}108,089 \\
17,719\end{array}$ & $\begin{array}{l}99,201 \\
16,262\end{array}$ & $\begin{array}{l}98,960 \\
16,222\end{array}$ & $\begin{array}{l}94,788 \\
15,539\end{array}$ & \begin{tabular}{|l|}
86,885 \\
14,243
\end{tabular} & $\begin{array}{l}63,190 \\
10,359\end{array}$ & $\begin{array}{r}45,764 \\
7,502\end{array}$ & $\begin{array}{l}88,194 \\
14,458\end{array}$ \\
\hline
\end{tabular}


TABLE 2.-CLASSIFICATION OF MATERIAL PER ACRE LEFT ON GROUND AFTER LOGGING

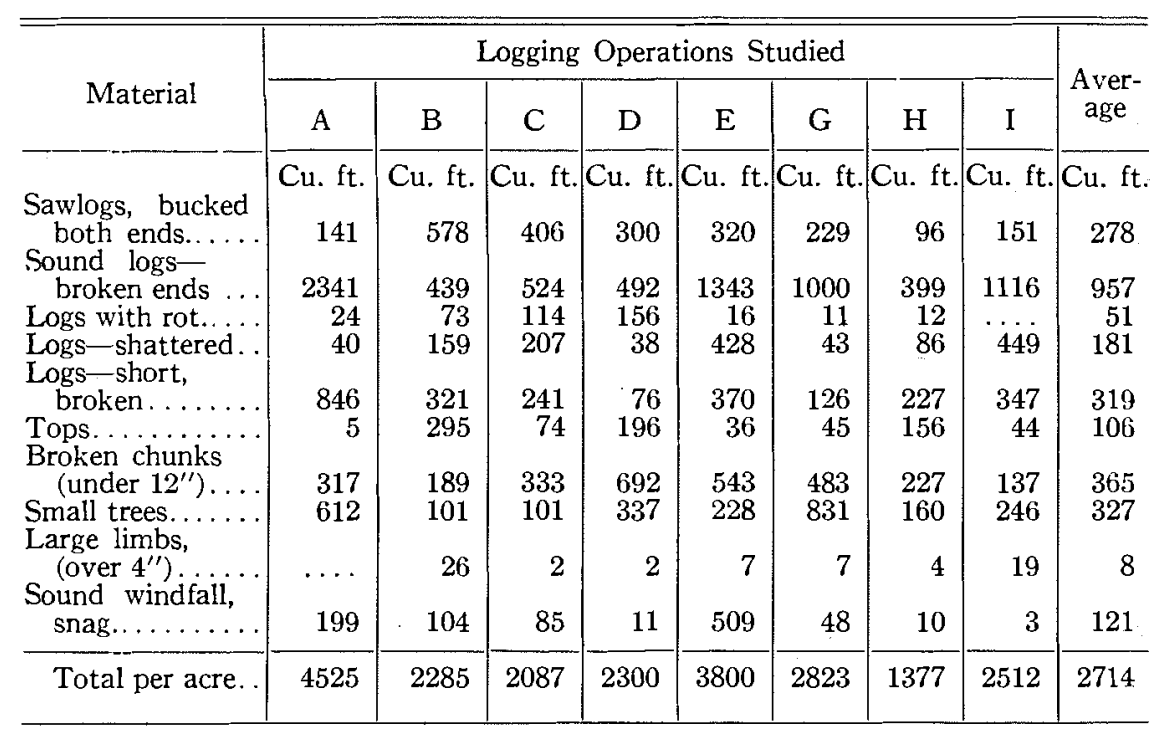

NOTE: To convert the above volumes in cubic feet to f.b.m., B.C. Log Scale, multiply by 6.1 .

In Tables 3 and 7, the material left on the ground after logging is segregated on the basis of its possible utilization. In this segregation, shattered sawlogs, short sections of sawlogs (less than 12 feet in length), broken chunks, large limbs, tops not suitable for poles or piling, and coarse " $B$ " class sawlogs, were considered as being fit only for cordwood or pulpwood, depending upon the species, and so tabulated. Table 3 is a summary of the information contained in Table 7. The f.b.m. and cubic foot volumes shown in these tables for the material suitable for sawlogs and the lineal foot and cubic foot values shown for piling and poles are based on actual measurements of length and of diameter at both ends of the piece.

The length and diameters of material suitable for pulpwood, cordwood, shingle bolts, and ties, were measured and their value in cubic feet determined. In tabulating the volume of the pulpwood and cordwood, however, an estimate of the number of cords has been made using a conversion factor of 100 cubic feet of solid material per cord. Considerable variation in the actual volume in a cord is to be expected on account of the variation in the size and shape of the pieces. The estimate of the number of cords is therefore only an approximation, the volume in cubic feet being the actual measured quantity of waste. 
TABLE 3.-SUMMARY OF MATERIAL PER ACRE LEFT ON GROUND AFTER LOGGING (CLASSIFIED AS TO POSSIBLE USES)

\begin{tabular}{|c|c|c|c|c|c|c|c|c|c|}
\hline \multirow{2}{*}{$\begin{array}{l}\text { Material } \\
\text { suitable for: }\end{array}$} & \multicolumn{8}{|c|}{ Logging Operation Studied } & \multirow{2}{*}{$\begin{array}{l}\text { Aver- } \\
\text { age }\end{array}$} \\
\hline & A & $\mathrm{B}$ & C & $\mathrm{D}$ & $\mathrm{E}$ & $G$ & $\mathrm{H}$ & I & \\
\hline Gawlogs $\because \ldots$, f.b.m. & $\begin{array}{r}10,931 \\
1,606\end{array}$ & $\begin{array}{l}7,323 \\
1,194\end{array}$ & $\begin{array}{r}6,067 \\
981\end{array}$ & $\begin{array}{r}2,704 \\
598\end{array}$ & $\begin{array}{l}9,770 \\
1,569\end{array}$ & $\begin{array}{l}6,336 \\
1,127\end{array}$ & $\begin{array}{r}1,833 \\
345\end{array}$ & $\begin{array}{r}4,092 \\
655\end{array}$ & $\begin{array}{l}6,132 \\
1,009\end{array}$ \\
\hline Piling. ..... lin. ft. & $\begin{array}{l}584 \\
474\end{array}$ & $\begin{array}{l}292 \\
170\end{array}$ & $\begin{array}{l}86 \\
64\end{array}$ & $\begin{array}{l}856 \\
536\end{array}$ & $\begin{array}{l}384 \\
300\end{array}$ & $\begin{array}{l}984 \\
649\end{array}$ & $\begin{array}{l}840 \\
386\end{array}$ & $\begin{array}{l}30 \\
13\end{array}$ & $\begin{array}{l}507 \\
324\end{array}$ \\
\hline $\begin{array}{r}\text { Poles. . . . . . lin. ft. } \\
\text { cu. ft. }\end{array}$ & $\cdots$ & $\begin{array}{l}99 \\
69\end{array}$ & $\begin{array}{l}198 \\
123\end{array}$ & 19 & $\begin{array}{l}18 \\
19\end{array}$ & $\begin{array}{l}47 \\
37\end{array}$ & . . & $\begin{array}{l}141 \\
123\end{array}$ & $\begin{array}{l}65 \\
48\end{array}$ \\
\hline Ties. . . . . . cu. ft. & $\cdots$ & $\because$ & 14 & 85 & 17 & & & & 15 \\
\hline $\begin{array}{r}\text { Pulpwood . . cords } \\
\text { cu. ft. }\end{array}$ & $\begin{array}{l}3.9 \\
392\end{array}$ & $\begin{array}{l}3.5 \\
345 \\
\end{array}$ & $\begin{array}{r}0.6 \\
62 \\
\end{array}$ & 1.5 & $\begin{array}{l}3.1 \\
305\end{array}$ & $\begin{array}{l}4.7 \\
474\end{array}$ & $\begin{array}{l}6.0 \\
597\end{array}$ & $\begin{array}{r}0.25 \\
24 \\
\end{array}$ & $\begin{array}{l}2.9 \\
294\end{array}$ \\
\hline $\begin{array}{r}\text { Cordwood. . cords } \\
\text { cu. ft. }\end{array}$ & $\begin{array}{r}20.5 \\
2,053\end{array}$ & $\begin{array}{l}4.5 \\
448\end{array}$ & $\begin{array}{l}7.1 \\
709\end{array}$ & $\begin{array}{l}9.2 \\
920\end{array}$ & $\begin{array}{r}15.7 \\
1,573\end{array}$ & $\begin{array}{l}5.3 \\
536\end{array}$ & $\begin{array}{r}0.5 \\
49 \\
\end{array}$ & $\begin{array}{r}16.1 \\
1,617\end{array}$ & $\begin{array}{l}9.9 \\
988\end{array}$ \\
\hline Shingle bolts cu.ft. & & 59 & 134 & & 17 & & $\cdots$ & 80 & 36 \\
\hline Total cubic feet: & 4,525 & 2,285 & 2,087 & 2,300 & 3,800 & 2,823 & 1,377 & 2,512 & 2,714 \\
\hline
\end{tabular}

In Table 4 the volume of the logging waste in each logging operation studied is expressed as a percentage of the volume of the merchantable timber, mensured to a commercial top diameter in advance of the fallers. This table shows a wide variation in the percentage of logging waste at the different operations studied. There are numerous factors, such as method of logging, topography, accessibility, etc., which would undoubtedly influence the degree

TABLE 4.-LOGGING WASTE IN RELATION TO VOLUME OF ORIGINAL STAND.

\begin{tabular}{|c|c|c|c|c|c|c|c|c|c|}
\hline \multirow{2}{*}{$\begin{array}{c}\text { Material } \\
\text { suitable for: }\end{array}$} & \multicolumn{8}{|c|}{ Logging Operation Studied } & \multirow{2}{*}{$\begin{array}{l}\text { Aver- } \\
\text { age }\end{array}$} \\
\hline & A & B & C & $\mathrm{D}$ & $E$ & $\mathrm{G}$ & $\mathrm{H}$ & I & \\
\hline 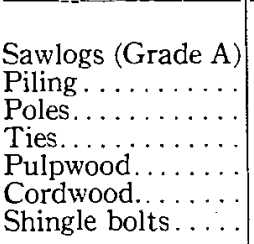 & $\begin{array}{c}\% \\
9.0 \\
2.7 \\
\ldots . \\
\dddot{2} .2 \\
11.5 \\
\ldots\end{array}$ & $\begin{array}{c}\% \\
6.7 \\
1.0 \\
0.4 \\
\cdots 1.9 \\
2.5 \\
0.4\end{array}$ & $\begin{array}{l}\% \% \\
6.0 \\
0.4 \\
0.7 \\
0.1 \\
0.4 \\
4.4 \\
0.8\end{array}$ & $\begin{array}{l}\% \% \\
3.7 \\
3.3 \\
0.1 \\
0.5 \\
0.9 \\
5.7 \\
\ldots .\end{array}$ & $\begin{array}{r}\% \\
10.1 \\
1.9 \\
0.1 \\
0.1 \\
2.0 \\
10.2 \\
0.1\end{array}$ & $\begin{array}{c}0 \% \\
7.9 \\
4.6 \\
0.2 \\
\ldots .3 \\
3.3 \\
\ldots \ldots\end{array}$ & $\begin{array}{l}\% \\
3.3 \\
3.7 \\
\ldots . \\
\ldots .8 \\
5.5 \\
\ldots .\end{array}$ & $\begin{array}{r}\% \\
8.7 \\
0.2 \\
1.6 \\
0.3 \\
21.6 \\
1.0\end{array}$ & $\begin{array}{l}\% \\
6.9 \\
2.2 \\
0.4 \\
0.1 \\
2.1 \\
7.6 \\
0.2\end{array}$ \\
\hline Total waste... & 25.4 & 12.9 & 12.8 & 14.2 & 24.5 & 19.8 & 13.3 & 33.4 & 19.5 \\
\hline
\end{tabular}

NOTE: In the above table the volume in cubic feet of the wood material left on the ground after logging is expressed as a percentage of the estimated merchantable volume in cubic feet of the original stand of timber cruised before falling. 
of utilization, breakage, etc. All operations studied, with the exception of "I," used the high-lead system of logging, using one spar tree. Operation "I," the topography of which was very rough, used the A-frame system, with the yarding donkey mounted on a float. All operations, with the exception of "H" which used a gasoline donkey, used comparatively large steam yarding donkey. The topography of the study areas, for all operations excepting "I" which was steep hillside, was comparatively smooth and level.

In Tables 5 and 6, the effect of species is shown on logging waste, the volume of the material left on the ground after logging being segregated by species and shown in cubic feet per acre in Table 5, while in Table 6 this total waste per species is shown in relation to the volume in $M$ f.b.m. of the original stand. As has already been explained, the volume in f.b.m. of the original stand was cruised only to a merchantable top diameter; actually the trees in the stand would contain a considerably greater volume of wood than is shown by the cruise of merchantable timber, so that in Table 6 a greater

TABLE 5.--TOTAL, WASTE IN CUBIC FEET PER ACRE, CLASSIFIED BY SPECIES.

\begin{tabular}{|c|c|c|c|c|c|c|c|c|}
\hline \multirow{2}{*}{ Species } & \multicolumn{8}{|c|}{ Logging Operation Studied } \\
\hline & $\mathrm{A}$ & $\mathrm{B}$ & $\mathrm{C}$ & $\mathrm{D}$ & $\mathrm{E}$ & G & $\mathrm{H}$ & $\mathrm{I}$ \\
\hline 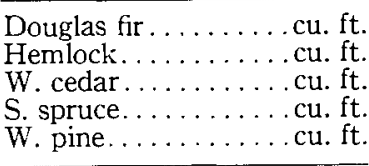 & $\begin{array}{r}3351 \\
1051 \\
123 \\
\ldots\end{array}$ & $\begin{array}{r}1106 \\
597 \\
243 \\
339 \\
\ldots \ldots\end{array}$ & $\begin{array}{r}1085 \\
168 \\
834 \\
\ldots \ldots \\
\ldots \ldots\end{array}$ & $\begin{array}{r}1826 \\
357 \\
43 \\
\cdots 74\end{array}$ & $\begin{array}{r}2824 \\
728 \\
174 \\
74 \\
\ldots \ldots\end{array}$ & $\begin{array}{r}1128 \\
1454 \\
83 \\
158\end{array}$ & $\begin{array}{c}204 \\
1173 \\
\ldots \ldots \\
\ldots \ldots \\
\ldots\end{array}$ & $\begin{array}{r}1912 \\
24 \\
576 \\
\ldots \ldots \\
\ldots \ldots\end{array}$ \\
\hline Total cubic feet. & 4.525 & 2285 & 2087 & 2300 & 3800 & 2823 & 1377 & 2512 \\
\hline
\end{tabular}

TABLE 6.-RELATION BETWEEN SPECIES AND LOGGING WASTE, SHOWING VOLUME OF WASTE IN CUBIC FEET PER M f.b.m. OF THE CORRESPONDING SPECIES IN THE ORIGINAL STAND.

\begin{tabular}{|c|c|c|c|c|c|c|c|c|c|}
\hline \multirow{2}{*}{ Species } & \multicolumn{8}{|c|}{ Logging Operation Studied } & \multirow{2}{*}{$\begin{array}{c}\text { Aver- } \\
\text { age }\end{array}$} \\
\hline & A & B & C & $\mathrm{D}$ & $\mathrm{E}$ & G & $\mathrm{H}$ & I & \\
\hline $\begin{array}{l}\text { Douglas fir....... } \\
\text { Western hemlock. } \\
\text { Western red cedar. } \\
\text { Sitka spruce... . . } \\
\text { Western white pine }\end{array}$ & $\begin{array}{r}\text { Cu. ft. } \\
46.7 \\
32.5 \\
25.7 \\
\ldots \\
\ldots\end{array}$ & $\begin{array}{r}\text { Cu. ft. } \\
\text { 14.8 } \\
35.5 \\
44.7 \\
30.2 \\
\ldots .\end{array}$ & $\begin{array}{c}\text { Cu. ft. } \\
12.9 \\
114.6 \\
59.2 \\
\ldots \\
\ldots\end{array}$ & $\begin{array}{r}\text { Cu. ft. } \\
19.1 \\
178.6 \\
81.9 \\
7 \ddot{7} .6\end{array}$ & $\begin{array}{c}\text { Cu. ft } \\
34.8 \\
78.2 \\
46.5 \\
123.3 \\
\ldots .\end{array}$ & $\begin{array}{c}\text { Cu. ft. } \\
16.3 \\
96.2 \\
96.5 \\
86.1\end{array}$ & $\begin{array}{c}\text { Cu. ft } \\
6.7 \\
35.7 \\
\ldots \\
\ldots \\
\ldots\end{array}$ & $\begin{array}{r}\text { Cu. ft } \\
45.5 \\
93.0 \\
165.1 \\
\ldots . \\
\ldots .\end{array}$ & $\begin{array}{c}\text { Cu. ft } \\
24.6 \\
83.0 \\
74.2 \\
76.7 \\
79.3\end{array}$ \\
\hline $\begin{array}{l}\text { Total waste per } \\
\text { M f.b.m. (all } \\
\text { species)........ }\end{array}$ & 41.7 & 20.4 & 21.0 & 23.2 & 43.7 & 32.4 & 21.8 & 55.0 & 32.4 \\
\hline
\end{tabular}


volume of waste may be indicated, if converted to board foot measure, than is shown in the original cruise.

\section{CONCLUSIONS}

This report deals with one forest type only, but it is considered that sufficient data have been assembled to permit of the following conclusions being drawn for this Douglas fir-western cedar type:-

TABLE 7.-TOTAL MATERIAL PER ACRE LEFT ON GROUND AFTER LOGGING, CLASSIFIED BY SPECIES AND BY POSSIBLE USES

\begin{tabular}{|c|c|c|c|c|c|c|c|c|}
\hline \multirow{2}{*}{$\begin{array}{l}\text { Material } \\
\text { Suitable for }\end{array}$} & \multicolumn{8}{|c|}{ Logging Operation Studied } \\
\hline & A & $\mathrm{B}$ & $\mathrm{C}$ & $\mathrm{D}$ & $\mathrm{E}$ & $\mathrm{G}$ & $\mathrm{H}$ & I \\
\hline 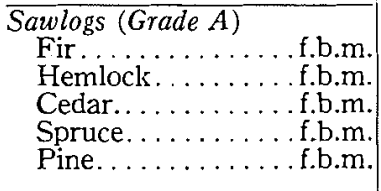 & $\begin{array}{r}9339 \\
1077 \\
515 \\
\cdots \\
\cdots\end{array}$ & $\begin{array}{r}4036 \\
1379 \\
328 \\
1580 \\
\cdots \\
\end{array}$ & $\begin{array}{r}3322 \\
302 \\
2443 \\
\cdots \\
\cdots \\
\end{array}$ & $\begin{array}{r}2544 \\
23 \\
\cdots \\
137 \\
\end{array}$ & $\begin{array}{r}7753 \\
1496 \\
521 \\
\cdots \\
\cdots \\
\end{array}$ & $\begin{array}{r}3971 \\
1946 \\
246 \\
173 \\
173 \\
\end{array}$ & $\begin{array}{r}752 \\
1081 \\
-\end{array}$ & $\begin{array}{l}3655 \\
437 \\
\cdots \\
\cdots\end{array}$ \\
\hline 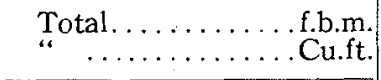 & $\begin{array}{r}10931 \\
1606\end{array}$ & $\begin{array}{l}7323 \\
1194 \\
\end{array}$ & $\begin{array}{r}6067 \\
981\end{array}$ & $\begin{array}{r}2704 \\
598\end{array}$ & $\begin{array}{l}9770 \\
1569\end{array}$ & $\begin{array}{l}6336 \\
1127\end{array}$ & $\begin{array}{r}1833 \\
345\end{array}$ & $\begin{array}{r}4092 \\
655\end{array}$ \\
\hline $\begin{array}{l}\text { Piling } \\
\quad \text { Fir............... } \\
\quad \text { Hemlock......... }\end{array}$ & $\begin{array}{r}10 \\
574\end{array}$ & $\begin{array}{r}63 \\
229 \\
\end{array}$ & $\begin{array}{l}13 \\
73\end{array}$ & $\begin{array}{l}549 \\
307\end{array}$ & $\begin{array}{r}46 \\
338\end{array}$ & $\begin{array}{l}110 \\
874\end{array}$ & $\begin{array}{r}72 \\
768\end{array}$ & $\begin{array}{l}30 \\
\cdots\end{array}$ \\
\hline $\begin{array}{r}\text { Total........... } \\
\ldots \ldots \ldots \ldots \text { lin.ft. } \\
\text {. cu.ft. }\end{array}$ & $\begin{array}{l}584 \\
474\end{array}$ & $\begin{array}{l}292 \\
170\end{array}$ & $\begin{array}{l}86 \\
64 \\
\end{array}$ & $\begin{array}{l}856 \\
536\end{array}$ & $\begin{array}{l}384 \\
300\end{array}$ & $\begin{array}{l}984 \\
649\end{array}$ & $\begin{array}{l}840 \\
386\end{array}$ & $\begin{array}{l}30 \\
13\end{array}$ \\
\hline $\begin{array}{l}\text { Poles } \\
\quad \text { Cedar............ lin.ft. } \\
\quad \text { cu.ft. }\end{array}$ & $\because$ & $\begin{array}{l}99 \\
69\end{array}$ & $\begin{array}{l}198 \\
123\end{array}$ & $\begin{array}{l}19 \\
11\end{array}$ & $\begin{array}{l}18 \\
19\end{array}$ & $\begin{array}{l}47 \\
37\end{array}$ & & $\begin{array}{l}141 \\
123\end{array}$ \\
\hline $\begin{array}{l}\text { Ties } \\
\quad \text { Fir.................. }\end{array}$ & $\because$ & $\cdots$ & 14 & 85 & 17 & . & & $\cdots$ \\
\hline $\begin{array}{l}\text { Pulpwood } \\
\quad \text { Hemlock.......... cords } \\
\text { Spruce } \ldots \ldots \ldots \ldots \text { cords }\end{array}$ & 3.9 & $\begin{array}{l}2.5 \\
1.0 \\
\end{array}$ & 0.6 & 1.5 & $\begin{array}{l}2.3 \\
0.8 \\
\end{array}$ & 4.7 & 6.0 & 0.25 \\
\hline 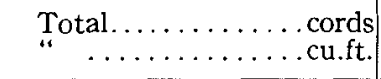 & $\begin{array}{l}3.9 \\
392\end{array}$ & $\begin{array}{l}3.5 \\
345\end{array}$ & $\begin{array}{r}0.6 \\
62\end{array}$ & $\begin{array}{l}1.5 \\
150\end{array}$ & $\begin{array}{l}3.1 \\
305\end{array}$ & $\begin{array}{l}4.7 \\
474\end{array}$ & $\begin{array}{l}6.0 \\
597\end{array}$ & $\begin{array}{r}0.25 \\
24\end{array}$ \\
\hline $\begin{array}{l}\text { Cordwood } \\
\quad \text { Fir } \ldots \ldots \ldots \ldots \ldots \\
\text { Cedar } \ldots \ldots \ldots \ldots \ldots \\
\text { Pine................ }\end{array}$ & $\begin{array}{r}20.3 \\
0.2 \\
\cdots\end{array}$ & $\begin{array}{r}4.0 \\
0.5 \\
\cdots \\
\end{array}$ & $\begin{array}{r}5.5 \\
1.6 \\
\cdots \\
\end{array}$ & $\begin{array}{l}8.2 \\
0.5 \\
0.5 \\
\end{array}$ & $\begin{array}{r}15.3 \\
0.4 \\
\cdots \\
\end{array}$ & $\begin{array}{l}3.9 \\
0.9 \\
0.5 \\
\end{array}$ & $\begin{array}{l}0.5 \\
\cdots \\
\cdots \\
\end{array}$ & $\begin{array}{r}13.4 \\
2.7 \\
\cdots \\
\end{array}$ \\
\hline $\begin{array}{r}\text { Total. . . . . . . . . cords } \\
\ldots \ldots \ldots \ldots \text { cu.ft. }\end{array}$ & $\begin{array}{l}20.5 \\
2053\end{array}$ & $\begin{array}{l}4.5 \\
448\end{array}$ & $\begin{array}{l}7.1 \\
709\end{array}$ & $\begin{array}{l}9.2 \\
920\end{array}$ & $\begin{array}{l}15.7 \\
1573\end{array}$ & $\begin{array}{l}5.3 \\
536\end{array}$ & $\begin{array}{r}0.5 \\
49\end{array}$ & $\begin{array}{l}16.1 \\
1617\end{array}$ \\
\hline $\begin{array}{l}\text { Shingle Bolts } \\
\quad \text { Cedar................. }\end{array}$ & $\ldots$ & 59 & 134 & $\cdots$ & 17 & $\cdots$ & $\cdots$ & 80 \\
\hline Total.............. cu.ft. & 4525 & 2285 & 2087 & 2300 & 3800 & 2823 & 1377 & 2512 \\
\hline
\end{tabular}

NOTE: Grade " $\mathrm{B}$ " sawlogs are included under "Pulpwood" or "Cordwood" depending upon species. 
1. As shown by Table 2, the principal forms of logging waste are (a) sound logs, suitable for sawlogs, that have been left because one (or both) end has been broken-the bucking of 2 to 4 feet from the shattered end would convert them into good sawlogs; (b) short sections of sawlogs resulting from tree breakage during falling; (c) trees too small to make sawlogs that have been overlooked or torn down during logging; and (d) sawlogs that have been overlooked by the yarding crew.

2. Table 3 shows that approximately 37 per cent of logging waste is suitable for Grade "A" sawlogs. At the present time no attempt is being made to salvage any of the material on the ground, but a little additional bucking and a more careful research for hidden sawlogs by the yarding crew would save much of this material which is suitable for Grade " $A$ " sawlogs, effecting a considerable reduction in the present amount of logging waste.

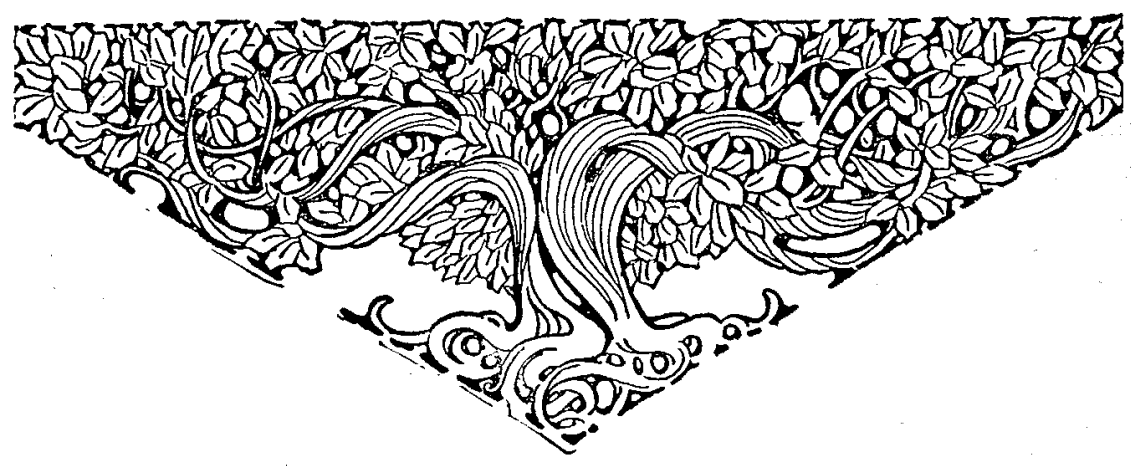

